\title{
The Impact of Tourists in Ecotourism Sites
}

\author{
Mohammad Nayef Alsarayreh \\ Al-Balqa Applied University, Jordan \\ E-mail: mohammad_n_k_s@yahoo.com
}

Received: Februaru 5, 2017 Accepted: Februaru 28, 2017 Published: April 17, 2017

doi:10.5296/bms.v9i1.12601ＵRL: https://doi.org/10.5296/bms.v9i1.12601

\begin{abstract}
Ecotourism and environmental balance is a new phenomenon aimed to research, study and meditate in nature, flora and fauna and the provision of human comfort. Ecotourism is the only way to maximize the economic, environmental and social benefits of tourism.

The main problem is represented in the difficulty of balancing the preservation of eco-tourism sites with the process of attracting tourists to eco-tourism sites.

A number of hypotheses have been developed, the most important of which are: There is no statistically significant negative impact of tourist on tourist sites.

The study concluded a number of results and the most important of these results is that the tourist has a negative impact on eco-tourism sites, represented by tourist's cutting trees, and dumping waste and dirt in streets which is an uncivilized act and harmful to the environment.

The study has also shown that tourists influence the eco-tourism sites since eco-tourism requires an environmental awareness, and the tourist should be aware that the protection of touristic sites is mandatory for everyone. The tourist's awareness has a great role in preserving the environment, so the educated tourist is necessary to preserve the eco-tourism sites.
\end{abstract}

The study has a set of recommendations, the most important of these recommendations:

- To increase the awareness of tourists about the importance of the environment and maintaining it by using leaflets that explain the importance of the environment for tourism,

- To intensify the penalties and legal procedures against the attacks on eco-tourism sites, and to modify laws and regulations in order to promote touristic services.

Keyword: Tourists, Ecotourism, environmental, tourism 


\section{Introduction}

The Jordanian environment is rich and diverse, as Jordan has natural wealth, which combines desert and countryside. Depending on this biodiversity, life, organisms, plants and animals vary. The country has established an institution concerned with the preservation of this biodiversity, the Royal Society for the Protection of Nature. This Society is responsible of a range of unique touristic sites, all of which are open to visitors. The Society encourages tourism and the environment, as it supports nature protection in many areas.

Ecotourism sites are attractive to tourists and satisfy their desires in terms of visiting various natural places and learning about their topography, vegetation and wildlife, as well as visiting local communities to learn about their customs and traditions.

The study of the behavior of tourists is very sensitive due to its association with the future of the tourism industry in order to maintain the sites of eco-tourism and tourism facilities, and ensure the continued flow of tourists to the eco-tourism sites as well as other factors affecting the behavior of the tourist. The matter that makes the tourist considers eco-tourism sites thoroughly and be motivated in the face of multiple variables, which often guide the tourist's behavior and attract him.

The environmental perspective is an attraction for tourists and their aspirations to enjoy and visit natural places, bearing in mind that this investment in the sources of the environment does not mean depletion and wasting natural resources but protecting and maintaining it for environmental tourism.

Generally, tourism and environment are complementary and overlapping sectors in vision and goals. Since a healthy environment is the right climate for sustainable tourism development. Sustainable tourism is based on sound environmental planning. Both, tourism and environment are two sectors that move together in harmony.

\section{Literature Review}

Al-Masoudi Study (2013) entitled "Archeological and Ecotourism and its Investment to Attain Sustainable Development," Demonstrated that the term sustainable development is not new, as it was mentioned in Holy Quran to confirm and to realize sustainable development and to preserve the rights of the Human beings (the populations) and the resources. The researcher commented that paying attention to archaeological and Ecotourism played an important role in finding economic activities that can produce more revenue with less costs, especially environmentaland social cost of as well as financial costs. The researcher has selected the city of Karbala (106) Km., South West of the city of Baghdad, as a model for research and investigation to reach a number of results such as: the important role of tourism in attracting investments in this sector.

Al-Ghamdi Study entitled "Towards More Effective Tourism Development in Jeddah: Issues Based on Features and Opinions of Tourists," stated that tourism has lately become amongst the most effective economic sectors, worldwide. High number of countries embarked on 
programs for developing domestic tourism, to achieve objectives such as: reducing leakage of money that happens through local tourists traveling to tourism areas abroad and making revenues through inbound tourists coming to domestic tourism areas. Indeed, tourism development has succeeded more where a comprehensive approach was adopted: that approach treats visitors for leisure as one category of tourists, others being those coming on year-round basis for other various purposes. including education, shopping, culture, sports, ...etc. This study classifies the tourism attractions in Jeddah - as a case study, and draws useful guidelines for the future of domestic tourism development. The study is primarily based on analyzing features and opinions of tourists. That is because tourist is the most capable of precisely determining what attracts him to particular tourism area, and what induces him to come back to it. It is hoped that this study will stimulate further research on this subject, for the benefit of the Saudi domestic tourism.

Abedel-Jaleel study (2014) entitled "The Interactive Relationship between Tourism and Sustainable Development," concentrated that eco-tourism is considered an important export industry, as it is dependent on natural ingredients with their various resources and wealth in addition to the physical ones built by people to attract tourists, it also has a prominent role in achieving sustainable development which represents the interface reflecting images of the development of nations and countries in all fields and directly related to the environment where it works to achieve the development goals on one hand and protecting the environment and its sustainability on the other hand.

Hanon Study (2015) entitled "Eco-Tourism and its impact in Jericho city as a case study: current status and sustainable strategies," aimed to study the environmental awareness and the awareness of Eco-Tourism concept for both: the local citizen and the visiting tourists of Jericho and to what extent do they understand the economic and social impact of Eco-Tourism in order to make a future perspective of the possibility to apply Eco-Tourism in the place of the study. Moreover, the study aimed to propose places and paths for Eco-Tourism in Jericho Governorate.

Khedheer Study (2005) entitled "the impact of local communities on Eco-Tourism establishments with concentration upon the criterion of designing the environmental hotel," deals with the mutual relationship between tourism and environment that represented a complex relationship for many researcher from various disciplines (tourism, environment and sociology.) This relationship has produced new environmental touristic trends that seek reconciliation with environment with its different systems. The emergence of these trend has been accompanied by new kind of environment friendly residential establishments called environmental hotels.

\section{The Importance of the Study}

Ecotourism and environmental balance is a new phenomenon that aims to research, study and reflect on nature, plants and animals and to provide comfort for humans. The advantage of eco-tourism is to link investment and productive projects to the local community while 
protecting the environment and biodiversity. The preparation of tourism programs based on directing tourism towards environmentally distinctive sites with emphasis on the practice of creative and entertaining tourist behavior, without harming the quality of the environment or impact it.

Although ecotourism has positive and beneficial things, one can not overlook the negative effects that may result from improper planning, which places ecotourism sites at great risk, especially with respect to environmental pollution, inappropriate land use, and sudden change in local community, the flow of more tourists, and the nature of the services they need, especially in the area of infrastructure such as transportation, communications, water, restrooms, facilities, and waste from new uses, which will be reflected on the environment, plant and animal wildlife, and the movement of birds. Here, it must be emphasized that dealing with ecotourism and natural resources sites "does not accept trial and error because losing it may mean not being retrieved again.

\subsection{Objective of the Study}

Jordan has a unique climate and diverse terrain that has led to a diversity of living organisms. In recent years, the focus has been on protecting the endangered species and preserving their habitat in certain areas. A number of nature reserves have been created to preserve biodiversity leading to diversity in Eco-Tourism sites.

There are many eco-tourism sites and many different tourism programs that have a negative impact on eco-tourism sites due to improper touristic practices and activities.

Ecotourism is considered the only way to maximize the economic, environmental and social benefits of tourism. In Ecotourism, everyone is seen as a stakeholder, and the need is to avoid shortcomings and the negative effects of the past that still face the country. This kind of tourism is gaining momentum by more and more travel, travel and tourism organizations meet the needs of eco-tourism tourists, and even promote eco-tourism in the country.

\subsection{The Study Problem}

The most successful touristic sites are currently based on clean physical environment, protected environments and characteristic cultural patterns of local communities. Areas that do not offer these characteristics suffer from a decline in the numbers and the quality of tourists, thereby reducing the economic benefits of local communities.

Tourism is a key factor in protecting environment when it is adapted to the local community and environment, through planning and sound management. This is available in an environment of natural beauty and interesting terrain, abundant wildlife, fresh air and clean water that attracts tourists.

The main problem is the difficulty of balancing the preservation of eco-tourism sites with the process of attracting tourists to eco-tourism sites. 


\subsection{The Questions of the Study}

This study aims to conclude results that help in identifying and determining the development of this kind of tourism in Jordan, the study will pursue to achieve these objectives through reducing:

The increase in the numbers of the tourists that represent a burden on touristic sites.

The damages in Eco-tourism sites due to lack controls and the bad treatment with these facilities by the tourists.

The swimming practices that harm the marine life of rare fish and coral reefs.

The spread of waste in the Eco-tourism sites.

\subsection{The Study Hypotheses}

The tourist has no statistical negative impact in influencing the Eco-tourism sites.

The touristic awareness has no statistical negative impact in influencing the Eco-tourism sites.

Tampering with Eco-tourism sites has no statistical negative impact in influencing the Eco-tourism sites.

Sate procedures have no statistical negative impact in influencing the Eco-tourism sites.

\subsection{The Methodology of the study}

This study belongs to explorative analytical studies and uses collection and analysis of data to reach the results. A questionnaire was designed in order to investigate the opinions of the sample of the study. 420 copies of the questionnaire were distributed, 400 copies were returned of them 7 copies were excluded so the study has depended on 393 responses of the worker in touristic sites representing the population and the sample of the study.

\section{The Statistical Analysis}

The description of the demographic characteristics of the respondents:

Table (1) indicates that $55.47 \%$ of the sample are males and $44.53 \%$ of them are females. It has shown that the age of $30.28 \%$ of the sample ranges 36 - 45 years old and $27.23 \%$ of them ranges 26 - 35 years old, $21.88 \%$ of the sample their age are 46 years old or over while $20.61 \%$ of them their ages ranges 18 - 25 years old.

The table also shows that the income of $40.75 \%$ of the sample ranges 200 - 500 JDs, 38.07\% their income ranges 501 - 1000JDs while 21.18\% their income exceeds 1000 JDs. 
Table 1. Frequencies and percentages of the personal variables of the respondents

\begin{tabular}{|l|l|l|l|}
\hline Variable & & Frequency & Percentage (\%) \\
\hline Gender & Male & 218 & 55.47 \\
\hline & Female & 175 & 44.53 \\
\hline Age & $18-25$ & 81 & 20.61 \\
\hline & $26-35$ & 107 & 27.23 \\
\hline & $36-45$ & 119 & 30.28 \\
\hline & $\geq 46$ & 86 & 21.88 \\
\hline Income & $200-500$ JDs & 152 & 40.75 \\
\hline & $501-1000$ JDs & 142 & 38.07 \\
\hline & $\geq 1000$ JDs & 99 & 21.18 \\
\hline
\end{tabular}

The first hypothesis: The tourist has no statistical negative impact in influencing the Eco-tourism sites.

Table (2) illustrates that the arithmetic means of all items were greater than 3.00 with observed significance level less than 0.05 which mean that these items are statistically significant, i.e., the tourist has a negative impact on the Eco-tourism sites by cutting trees, laying down wastes in the streets forming a harmful uncivilized environmental view.

All items together has got an arithmetic mean of 4.31 that is greater than 3.00 with significance level less than 0.05 which means that it is statistically significant implying that The tourist has a negative impact in influencing the Eco-tourism sites.

Table 2. Arithmetic Means, Standard Deviations, t-values and significance levels related to

\begin{tabular}{|l|l|l|l|l|l|}
\hline No. & Item & & & & \\
\hline 1 & Does the tourist have a negative impact on Eco-tourism sites & 4.33 & 0.69 & 0.69 & 0.00 \\
\hline 2 & $\begin{array}{l}\text { Does cutting trees by tourist harm environment and } \\
\text { negatively impact Eco-tourism sites }\end{array}$ & 4.56 & 0.70 & 0.70 & 0.00 \\
\hline 3 & $\begin{array}{l}\text { Does the dumping of waste by the tourist lead to pollution of } \\
\text { the environment and adversely affect the eco-tourism sites }\end{array}$ & 3.91 & 0.88 & 0.88 & 0.00 \\
\hline 4 & $\begin{array}{l}\text { Is throwing dirt on the street by the tourist landscape } \\
\text { non-civilization harmful to the environment and adversely } \\
\text { affect eco-tourism sites }\end{array}$ & 4.46 & 0.72 & 0.72 & 0.00 \\
\hline & Sum & & & & \\
\hline
\end{tabular}




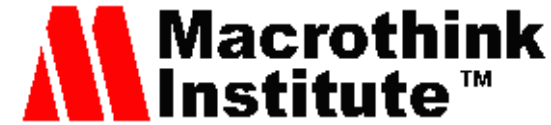

The second hypothesis: The touristic awareness has no statistical negative impact in influencing the Eco-tourism sites.

Table (3) illustrates that the arithmetic means of all items were greater than 3.00 with observed significance level less than 0.05 which means that it is statistically significant, i.e., there is a role in influencing the eco-tourism sites through the fact that eco-tourism requires environmental awareness, and the tourist's awareness that the protection of tourist sites is an environment that is obligatory for everyone. The tourist's awareness that it has a great role in preserving the environment, And an educated tourist to preserve the eco-tourism sites.

All items together has got an arithmetic mean of 3.69 that is greater than 3.00 with significance level less than 0.05 which means that it is statistically significant. So, the second hypothesis is rejected as the touristic awareness has a negative impact in influencing the Eco-tourism sites.

Table 3.Arithmetic Means, Standard Deviations, t-values and significance levels related to

\begin{tabular}{|l|l|l|l|l|l|}
\hline No. & Item & & & & \\
\hline 5 & $\begin{array}{l}\text { Do think that eco-tourism require environmental awareness } \\
\text { since it has a role in influencing on eco-tourism sites }\end{array}$ & 4.05 & 0.96 & 21.74 & 0.00 \\
\hline 6 & $\begin{array}{l}\text { The awareness of the tourist that protecting eco-tourism site } \\
\text { is mandatory for all has a role in influencing the } \\
\text { eco-tourism sites }\end{array}$ & 3.35 & 1.00 & 6.90 & 0.00 \\
\hline 7 & $\begin{array}{l}\text { The awareness of the tourist in maintaining eco-tourism } \\
\text { sites has a role in influencing the eco-tourism sites }\end{array}$ & 3.46 & 1.07 & 8.43 & 0.00 \\
\hline 8 & $\begin{array}{l}\text { Do you think that ecotourism needs an educated citizen and } \\
\text { tourist to preserve eco-its sites }\end{array}$ & 3.92 & 0.99 & 18.48 & 0.00 \\
\hline & Sum & 3.69 & 0.70 & 19.61 & 0.00 \\
\hline
\end{tabular}

The third hypothesis: Tampering with Eco-tourism sites has no statistical negative impact in influencing the Eco-tourism sites.

Table (4) illustrates that all items except item (9) have got arithmetic means greater than 3.00 with observed significance levels less than 0.05 so that it is statistically significant, i.e., the pollution of the sea has a dangerous effect on the environment and impact eco-tourism and Organisms on the globe and destroying the quality of the environment. Item (9) has got an arithmetic mean less than 3.00 so it is statistically insignificant.

All items together has got an arithmetic mean of 3.15 that is greater than 3.00 with 
significance level less than 0.05 which means that it is statistically significant. So, the third hypothesis is rejected as tampering with Eco-tourism sites has a negative impact in influencing the Eco-tourism sites.

Table 4. Arithmetic Means, Standard Deviations, t-values and significance levels related to

\begin{tabular}{|c|c|c|c|c|c|}
\hline No. & Item & 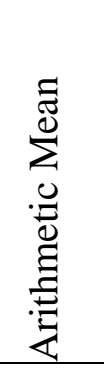 & $\dot{\varphi}$ & 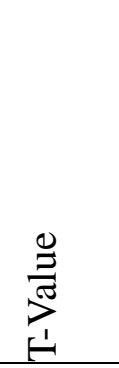 & $\begin{array}{l}0 \\
0 \\
0 \\
0 \\
0 \\
0 \\
0 \\
0\end{array}$ \\
\hline 9 & $\begin{array}{l}\text { Do you think the impact of the behavior of the } \\
\text { tourist in eco-tourism sites leads to the spread of } \\
\text { diseases causes environmental pollution and } \\
\text { contributes in influencing eco-tourism? }\end{array}$ & 2.61 & 1.52 & -5.06 & 0.00 \\
\hline 10 & $\begin{array}{l}\text { Do you think that the impact of sea pollution is } \\
\text { dangerous to the environment due to pollution of } \\
\text { the environment because of its role in influencing } \\
\text { environmental tourism? }\end{array}$ & 3.91 & 1.17 & 16.23 & 0.00 \\
\hline 11 & $\begin{array}{l}\text { Do you think that the effect of water pollution } \\
\text { affects the living organisms on the planet due to } \\
\text { pollution of the environment because of its role } \\
\text { in influencing environmental tourism? }\end{array}$ & 3.15 & 1.08 & 1.92 & 0.03 \\
\hline \multirow[t]{2}{*}{12} & $\begin{array}{l}\text { Do you think that the negative impacts of } \\
\text { eco-tourism such as environmental quality } \\
\text { destruction, tourism distortion and pollution have } \\
\text { a role in influencing ecotourism? }\end{array}$ & 3.39 & 1.56 & 5.16 & 0.00 \\
\hline & Sum & 3.15 & 1.13 & 2.63 & 0.01 \\
\hline
\end{tabular}

The fourth hypothesis: Sate procedures have no statistical negative impact in influencing the Eco-tourism sites.

Table (5) illustrates that all items except item (15) have got arithmetic means greater than 3.00 with observed significance levels less than 0.05 so that it is statistically significant, i.e., the procedures of the state have a role in preserving the environment and ecotourism sites, and the state procedures have increased in the level of eco-tourism services after the supervision of the Ministry of Tourism on eco-tourism sites, and the provisions of the law and legal procedures need to be adjusted in harmony with current developments in the world to maintain eco-tourism sites. Item (15) obtained a mean less than 3.00, which is statistically insignificant.

All items together has got an arithmetic mean of 3.86 that is greater than 3.00 with 


\section{Macrothink}

significance level less than 0.05 which means that it is statistically significant. So, the fourth hypothesis is rejected so Sate procedures have a negative impact in influencing the Eco-tourism sites.

Table 5. Arithmetic Means, Standard Deviations, t-values and significance levels related to

\begin{tabular}{|c|c|c|c|c|c|}
\hline No. & Item & 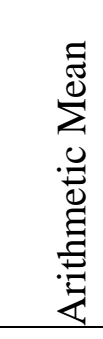 & $\dot{\varphi}$ & 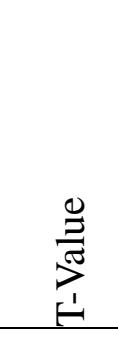 & 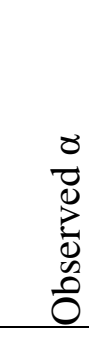 \\
\hline 13 & $\begin{array}{l}\text { Do you think that state actions have } \\
\text { a role in preserving the environment } \\
\text { and ecotourism sites? }\end{array}$ & 4.28 & 0.71 & 29.65 & 0.00 \\
\hline 14 & $\begin{array}{l}\text { Do you think that the state } \\
\text { procedures have increased in the } \\
\text { level of eco-tourism services after } \\
\text { the Ministry of Tourism supervision } \\
\text { of the eco-tourism sites }\end{array}$ & 4.51 & 0.73 & 33.95 & 0.00 \\
\hline 15 & $\begin{array}{l}\text { Are you satisfied with the actions } \\
\text { taken by the state against those who } \\
\text { attack eco-tourism sites? }\end{array}$ & 2.76 & 1.12 & -3.47 & 0.00 \\
\hline 16 & $\begin{array}{l}\text { Do you think that the provisions of } \\
\text { the law and the legal procedures } \\
\text { need to be adjusted in harmony with } \\
\text { the current developments in the } \\
\text { world to preserve ecotourism sites? }\end{array}$ & 3.90 & 0.87 & 16.90 & 0.00 \\
\hline & Sum & 3.86 & 0.49 & 28.63 & 0.00 \\
\hline
\end{tabular}

\section{Results}

$1 \mathrm{~W}$ - There is a statistical significant negative impact of the tourist in influencing eco tourism sites. As the tourist has a negative impact on eco-tourism sites, by cutting trees, and dumping waste and dirt in the street in an uncivilized and harmful manner to the environment.

2 - There is a statistical significant negative impact of touristic awareness in influencing 
eco-tourism sites, as influencing ecotourism sites requires environmental awareness, and the awareness of the tourist that the protection of eco-tourism sites is a duty of everyone, and the touristic awareness has a significant role in the preservation of eco-tourism sites, moreover an educated citizen and tourist is required to preserve eco-tourism sites.

3 - There is a statistical significant negative impact of tampering with ecotourism sites. The impact of sea pollution is dangerous to the environment and has a role in influencing ecotourism. The effect of water pollution affects the living organisms on the planet and has a role in influencing ecotourism, moreover there are negative effects of eco-tourism such as the destruction of environmental quality, distortion of tourist areas and pollution.

4 - There is a statistically significant negative impact of the State's actions in influencing ecotourism sites. As the state's actions have a role in preserving the environment and ecotourism sites, and the state's procedures have increased in the level of ecotourism services after the Ministry of Tourism supervision of eco-tourism sites, and the provisions of the law and legal procedures need to be adjusted in harmony with the current developments in the world to maintain sites Eco-tourism.

\section{Recommendations}

1 - to take care in educating the tourist about the importance of the environment and maintaining it through the publication of illustrative leaflets of the importance of the environment for tourism.

2 - Put plates showing that the logging is prohibited and tampering leads to the destruction of the tourist site.

3 - Put plates showing that the dumping of waste should be in the space allocated to him to reduce the proportion of visual pollution in the sites of environmental tourism.

4 - The development of plates showing that the dumping of dirt into the sea water is prohibited and that pollution resulting in skin diseases and the killing of the marine environment.

5. Extensive penalties and legal procedures in case of attacks on eco-tourism sites.

6. Amend the regulations and laws so as to upgrade the level of tourism services.

\section{References}

AbedelJaleel, H. (2014). The Interactive Relationship between Ecotourism and Sustainable Development, Journal of Social Studies and Research, Wadi University, 9, Algeria.

Al-Ghamdi, A., \& Mohammed, A. H. (2003). Towards a more effective tourism development in Jeddah city: based on an analysis of the characteristics and desires of tourists, King Abdul Aziz University Journal: Engineering Sciences, p.14, p.1.

Al-Masoudi, R., \& Mohamed, A. O. (2013). Environmental and Archaeological Tourism in 


\section{Macrothink}

Karbala Governorate and its Investment in Sustainable Development, Journal of Geographical Research, No. 18, Iraq.

Andy, D., \& Alan, M. (2004). Ecotourism development a manual for conservation planners and managers. Arlington: Virginian. USA. Vol (1).

Buckly, R. (2009). Ecotourism principles and practices. International center for ecotourism research. Griffith university. CABI, oxford: UK.

Ibrahim, O. (2008). Pharaonic, Graeco-Roman and Coptic Archaeological sites in the Fayoum Involved in Eco-Tourism Programmes", Unpublished Ph.D, Faculty of Tourism and Hotels, Tourism Guidance Department, Fayoum Universit.

Khadair, L., \& Mohamed, M. (2005). Impact of Local Communities on Ecotourism with Emphasis on Environmental Hotel Design Criteria, Master Thesis, Ain Shams University, Egypt.

Mohamed, H. M. (2015). Environmental Tourism in Jericho Governorate: Current Status and Sustainability Strategies, Master Thesis, Bir Zeit University, Palestine.

Parker, S., \& Khare, A. (2005). Understanding Success Factors for Ensuring Sustainability in Ecotourism Development in Southern Africa. Journal of Ecotourism, 4(1), 32-46.

Seth, M. L. (1977). Theory and practice of Economic Planning, New Delhi.

\section{Copyright}

Copyright for this article is retained by the author(s), with first publication rights granted to the journal.

This is an open-access article distributed under the terms and conditions of the Creative Commons Attribution license (http://creativecommons.org/licenses/by/4.0/). 